\title{
Kryzysy (neo)liberalizmu a funkcjonowanie reżimów międzynarodowych
}

\author{
Crises of (neo)liberalism and the functioning of international regimes
}

\section{Wprowadzenie}

Pojawienie się kryzysu zazwyczaj prowadzi do zakwestionowania dotychczasowych wzorów postępowania i standardów funkcjonowania danego systemu. Skutkiem tego jest nierzadko odejście od dominującej ideologii oraz przebudowa istniejących struktur wedle nowych wzorców i paradygmatów. Proces ten odbywa się gwałtowne i przybiera postać rewolucji lub toczy się stopniowo, przy zachowaniu elementów poprzedniego ustroju. Zawsze jednak zmianie towarzyszy niepewność, lęk oraz poczucie utraty kontroli, które czasami przeradza się w wolę powstrzymania przekształceń za pomocą dostępnych recept oraz środków. Powyższe ulega zwielokrotnieniu w przypadku wielości kryzysów naraz dotykających różne płaszczyzny danego systemu. Jednak perturbacje te dają także szansę na korektę ujawniających się nieprawidłowości poprzez wygenerowanie zupełnie nowych instytucji, bardziej odpowiadających aktualnym wyzwaniom.

Celem niniejszego artykułu jest analiza funkcjonowania idei neoliberalnych w dobie rozmaitych kryzysów międzynarodowych, dotykających m.in. świat Zachodu. W konsekwencji tekst pracy koncentruje się na weryfikacji następującej hipotezy badawczej: funkcjonowanie doktryny neoliberalizmu przyczynia się do stopniowej transformacji instytucji świata zachodniego, powodując spadek znaczenia tej strefy, z uwagi na m.in. rosnące tam nierówności społeczne.

Metodą zastosowaną w tym tekście jest jakościowa analiza wybranych publikacji poświęcanych rozpatrywanemu paradygmatowi w aspekcie różnych kryzysów 
rozgrywających się w przestrzeni międzynarodowej, przy użyciu m.in. narzędzi szkoły prawa i ekonomii (dalej: Law\&Economics lub L\&E)1. Założeniem tego tekstu jest wykorzystanie jedynie ogólnej teorii ekonomiczno-społecznej do analizy wybranych syndromów kryzysu doktryny neoliberalnej. Weryfikacja powyższej hipotezy z pewnością wymaga bardziej zaawansowanych studiów o charakterze empirycznym w odniesieniu do konkretnych aktów prawnych na gruncie tak lokalnym, jak i międzynarodowym za pomocą metodologii $L \& E$. Bez wątpienia należałoby również w osobnym opracowaniu skupić się na innych wykładniach liberalizmu, począwszy od klasycznej teorii liberalnej Johna S. Milla, a skończywszy na ordoliberalizmie Ludwiga Erharda. Wnioski zawarte w niniejszym artykule mają charakter autorski i wynikają z selektywnej analizy dyskursu w oparciu o indywidualny dobór literatury przedmiotu.

\section{Funkcjonowanie neoliberalizmu w stosunkach międzynarodowych - perspektywa ekonomicznej analizy prawa}

Warto rozpocząć od konstatacji, że geneza neoliberalizmu wiązała się z krytyką powojennego keynesizmu optującego za koncepcją silnego państwa, które odgrywa istotną rolę w gospodarce za pomocą zakrojonej na szeroką skalę interwencji w procesy ekonomiczne. W latach 70. XX w. doszło bowiem do załamania modelu gospodarczego, który został zaimplementowany i przyniósł realne prosperity w okresie powojennym. Państwa zachodnie doświadczyły wówczas głębokiego kryzysu swych struktur, którego przejawem stało się m.in. bezrobocie, inflacja oraz upadek międzynarodowego systemu walutowego. Zapaść ta skłoniła świat

\footnotetext{
1 Ekonomiczna analiza prawa (ang. law and economics) - dyscyplina znajdująca się między ekonomią a naukami prawnymi. Zajmuje się badaniem prawa i polityki, korzystając z metod nauk ekonomicznych. Kładzie szczególny nacisk na badanie efektywności regulacji prawnych. Wykorzystując instrumentarium nauk ekonomicznych, dąży do wskazania kierunków aktywności państwa w obszarze prawodawstwa, polityki i gospodarki. Promuje ona często postulat podporządkowania działalności władz wyłącznie zasadom ekonomicznej użyteczności. Szkoła prawa i ekonomii skupia się na przewidywaniu efektów regulacji dla funkcjonowania gospodarki, badając, czy przyjęte regulacje są efektywne pod względem ekonomicznym. Dorobek tej dziedziny jest wykorzystywany do ewaluacji, za pomocą metod ekonomicznych, rezultatów rozwiązań prawnych przed/po wprowadzeniu regulacji. Dodatkowo formułuje ona rekomendacje, bazując na regułach płynących z ekonomii, dla przyszłej aktywności rządu w obszarze prawodawstwa. Postulując propozycje zmian, oddziałuje na władze publiczne w celu generowania aktów legislacyjnych, które byłyby bardziej korzystne dla podmiotów życia zbiorowego. Do jej głównych przedstawicieli zalicza się Richarda Posnera oraz Gary Beckera (Cooter i Ulen, 2011).
} 
zachodni do zdystansowania się od rozwiązań New Deal na rzecz nowych trendów wolnorynkowych, które przybrały postać tzw. reaganomiki oraz thatcheryzmu². Doszło do transformacji tamtejszych gospodarek wedle prawideł neoliberalnych, które dość szybko stały się naczelną i bezalternatywną teorią ładu społeczno-gospodarczego i politycznego Zachodu (pod hasłem: „There Is No Alternative”). Sprzężony z analizowaną doktryną proces globalizacji doprowadził do transmisji neoliberalizmu do innych części świata jako swoistego „odwiecznego prawa natury", którego logiki nie można zatrzymać. Zdaniem jednego z głównych przedstawicieli prezentowanej teorii, Friedricha von Hayeka, wolny rynek był bowiem przykładem porządku naturalnego, którego kwestionowanie wykracza poza ramy zdrowego rozsądku. Będąc nowym „kamieniem filozoficznym”, neoliberalizm - ze względu na swoją uniwersalność - miał być kompatybilny niemal ze wszystkimi systemami gospodarczymi, bez względu na ich uwarunkowania społeczne czy kulturowe. W ramach prezentowanej doktryny naczelną koncepcją antropologiczną stawał się tzw. homo oeconomicus, czyli jednostka dbająca o własny interes materialny poprzez maksymalizację zysku oraz minimalizację kosztów, której potrzeby miały być w pełni zaspokojone przez instytucje wolnorynkowe. Powyższemu przeświadczeniu wtórował rozwój nauk z pogranicza prawa i ekonomii, który doprowadził m.in. do wyłonienia modelu $L \& E$.

Implementacja prawideł neoliberalnych niewątpliwie przyczyniła się do wyjścia z kryzysu lat 70. XX w. oraz skutkowała wzrostem i rozwojem gospodarczym struktur świata zachodniego. Doprowadziła ona również do klęski systemu komunistycznego, a następnie globalnej dyfuzji reguł demokracji liberalnej, czego rezultatem stała się m.in. transformacja polityczno-gospodarcza krajów Europy Środkowo-Wschodniej po 1989 r. Triumf zasad wolnorynkowych wedle dogmatów szkoły chicagowskiej ${ }^{3}$ wiódł do bezprecedensowej dominacji Zachodu, w tym w szczególności Stanów Zjednoczonych w ramach jednobiegunowego świata po rozpadzie ZSRR. Analizowana idea nie tylko dostarczała rzeczowych argumentów uzasadniających wprowadzanie zmian, lecz także stała się jedynym zdroworozsądkowym rozwiązaniem, którego paradoksalnie nie interpretowano jako jednej z opcji do wyboru. Neoliberalizm był bowiem prezentowany w państwach kapitalistycznych jako niepolityczne rozwiązanie

2 Poglądy i będąca ich wynikiem działalność Ronalda Reagana, prezydenta USA w latach 1981-1989, oraz Margaret Thatcher, która pełniła urząd premiera Wielkiej Brytanii w latach 1979-1990.

3 Chicagowska szkoła w ekonomii - szkoła w ekonomii, powstała w latach 30. XX w. na University of Chicago. Do poglądów jej przedstawicieli (takich jak Milton Friedman) należała wiara w skuteczność wolnego rynku w zakresie alokacji zasobów i podziału dochodów oraz minimalizowanie roli państwa w działalności gospodarczej (Duménil i Lévy, 2011). 
niemal wszystkich skomplikowanych problemów gospodarczych, jawiąc się jako niezawodny przepis na jedyną i właściwą wykładnię procesów ekonomicznych (Kotz, 2001, s. 93-109). Sądzono, że analizowana doktryna wyraża naturalny porządek rzeczy, który powinien stanowić podstawę polityki gospodarczej w krajach rozwiniętych, co zostało dodatkowo wzmocnione uwidaczniającym się wówczas szybkim wzrostem i rozwojem gospodarczym całego regionu.

Neoliberalizm zakładał w istocie przeniesienie szeroko pojętej władzy społecznej ze struktur politycznych do zderegulowanych rynków, które miały kierować się obiektywnymi prawami, dającymi się wyjaśnić za pomocą modeli matematycznych. W obawie przed populizmem ekonomia została wyjęta spod kontroli politycznej poprzez ustanowienie instytucji wolnych od bezpośrednich decyzji wyborczych lub referendalnych. Rynek miał działać w sposób niezakłócony głębszą interwencją państwa, co gwarantowało jego zwiększoną efektywność, gdyż to protekcjonizm i interwencjonizm obwiniano za problemy gospodarcze lat 70. XX w. Wolny rynek występował w tym ujęciu jako optymalny mechanizm alokacji, który najlepiej zaspokaja większość potrzeb, chroniąc duże zbiorowości przed biedą oraz konfliktami społecznymi (Bairoch i Kozul-Wright, 1998, s. 37-68). Doskonałym zamiennikiem polityki stawały się więc mechanizmy wolnorynkowe, których wdrożenie miało być patentem na wzrost i dobrobyt $\mathrm{z}$ uwagi na osłabienie arbitralnego wpływu rządów na gospodarkę. W razie zaistnienia nieprawidłowości wolny rynek zapewniał niezbędną korektę i samoregulację, a każda interwencja z zewnątrz mogła tylko zaburzyć jego naturalny stan równowagi. Zgodnie z przewidywaniami teoretycznymi uwolniony rynek w niemal wszystkich obszarach życia doprowadził do serii sukcesów przejawiających się w finansowej stabilności, wzroście gospodarczym oraz utrzymywaniu inflacji na niskim poziomie.

W ten sposób doszło do liberalizacji przepływów kapitałowych oraz znoszenia ceł $\mathrm{b}$ barier administracyjnych w handlu międzynarodowym. Redukcja wysokości podatków dla biznesu skłoniła do szeroko zakrojonych inwestycji w ramach sektora prywatnego. Rządy kierujące się wspomnianą doktryną ograniczyły wydatki socjalne i tym samym zmniejszyły skalę redystrybucji, a zarazem uelastyczniły rynki pracy. Prezentowana doktryna zakładała prywatyzację przedsiębiorstw państwowych, ograniczenie roli związków zawodowych oraz ochrony socjalnej pracownika. Prywatyzacja miała zapewnić najbardziej efektywną alokację czynników produkcji i usuwała nieefektywności sektora publicznego. Uważano, że bogactwo jest generowane głównie przez przedsiębiorstwa, a nie przez władze publiczne, których rolą było tylko zapewnienie właściwej infrastruktury dla biznesu. Powyższe wynikało z tzw. „teorii skapywania” (tzw. trickle-down 
theory), która głosiła, że jedynie bogaci mogą tworzyć dobrobyt, który następnie „skapuje” na pozostałych uczestników społeczeństwa (Glyn, 1998, s. 391-409). Z tego względu działania redystrybucyjne państwa miały ograniczać się do niezbędnego minimum. Interwencję socjalną miał w istocie zastąpić wolny rynek, który stanowił doskonale samoregulujący się mechanizm. W analizowanym modelu spójność społeczna schodziła na dalszy plan. Jej miejsce zajmowało społeczeństwo konsumpcyjne, w którym samorealizacja następuje w drodze jak najszybszego zaspokajania potrzeb materialnych człowieka. Tradycyjne wartości miały ustępować kosmopolityzmowi wspierającemu ideę mobilności siły roboczej na globalnym rynku, co wpisywało się w komercjalizację życia, w którym wszystko jest towarem lub usługą.

Doktryna neoliberalna nie tylko odcisnęła piętno na płaszczyźnie ekonomicznej, lecz także na ustroju prawnym państw zachodnich oraz ich szeroko pojętej kulturze politycznej i modelu społecznym (Dunne, 2008, s. 110-121). Projekt ten polegał bowiem na wdrażaniu reguł demokracji liberalnej zakładającej wzmocnienie m.in. praw jednostki oraz trójpodziału władzy, ze szczególnym uwypukleniem roli sądownictwa (zwłaszcza konstytucyjnego). Nośnikiem tych idei miało być samoorganizujące się społeczeństwo obywatelskie, pielęgnujące tolerancję oraz pluralizm światopoglądowy. W tym paradygmacie zauważalna była niechęć do niczym nieograniczonych rządów politycznej większości, której wola mogła wyrodzić się w autokrację zagrażającą prawom jednostek, co przywoływały tragiczne doświadczenia II wojny światowej. System demokracji liberalnej miał zatem chronić mniejszości przed ich tyranizowaniem ze strony większości. Niekontrolowana demokracja mogła wszak skończyć się dyktaturą, która zaszkodzi interesom obywateli (Diamond, 1999, s. 12). Z tego względu filarem demokracji liberalnej było funkcjonowanie niezależnych i samodzielnych instytucji, które pozostawały wolne od wpływu wyborczego bądź referendalnego. Przeniesienie części władzy publicznej do gremiów niepodlegających bezpośredniej weryfikacji wyborczej, tj. sądów, banku centralnego czy organizacji międzynarodowych, miało wzmacniać praworządność zakotwiczoną w systemie tzw. checks and balances. Owa nieufność do demosu i woli większości wiodła do formuły rządu ekspertów i technokratów działających na rzecz pragmatycznych rozwiązań skomplikowanych problemów w duchu m.in. szkoły prawa i ekonomii. Wyzwolona od ideologii władza oświeconych miała być bowiem w stanie zaproponować racjonalne i merytoryczne rozstrzygnięcie trudnych dylematów, których lud często nie rozumiał (Dawson iHanley, 2016, s. 20). Rządy większości postrzegane były jako potencjalne zagrożenie dla swobód obywatelskich, dlatego przyjmowano, że demokracja to rodzaj luksusu, na który można sobie pozwolić 
jedynie w warunkach względnego dostatku oraz istnienia silnej klasy średniej. W ramach neoliberalizmu doszło zatem do wyniesienia na piedestał ekspertów (profesjonalistów, prawników, akademików, bankierów itp.), którzy - jako nowe elity - mieli ochronić prawa jednostek oraz kapitału. Legitymizacja demokracji liberalnej następowała w drodze argumentów utylitarnych, wskazujących na oczywistą poprawę życia w ramach tego ustroju, co potwierdzały badania prowadzone m.in. w ramach nurtu $L \& E$. Zgoda ludu na ten system została wydana w zamian za obietnicę pokoju, dobrobytu i bezpieczeństwa, które w początkowej fazie neoliberalnej globalizacji wydawały się być zapewnione na Zachodzie.

W polityce międzynarodowej analizowana doktryna odznaczała się z kolei dynamicznymi postępami procesu globalizacji, deterytorializacji oraz uniwersalizacji (Duménil i Lévy, 2011, s. 113). Ponadnarodowe reżimy prawne miały sprzyjać przenoszeniu kompetencji rządów z poziomu narodowego na płaszczyznę ponadnarodową. Powstające w tym okresie wieloskładnikowe mechanizmy regulacyjne, nasycone racjonalistyczną, zachodnioeuropejską myślą prawno-polityczną i gospodarczą, prowadziły do ograniczenia roli państw narodowych zaplątanych w rozmaite sieci współzależności. Charakterystyczna dla gospodarek kapitalistycznych deregulacja miała za zadanie zapewnić swobodę cyrkulacji czynników produkcji w skali globalnej. Uważano, że rządy narodowe w dobie turbokapitalistycznej globalizacji nie były bowiem w stanie samodzielnie realizować potrzeb jednostek. Świat współzależności zweryfikował pojęcie suwerenności i podmiotowości, przechylając zatem szalę na rzecz organizacji międzynarodowych o wymiarze gospodarczym i integracyjnym. $\mathrm{Na}$ bazie wspólnych wartości ekonomicznych miało dojść do budowy ponadnarodowych podmiotów polityki światowej, gwarantujących swobodę przepływu towarów, usług i kapitału oraz mobilność ludzi, co oceniano jako niezwykle korzystne zjawisko z punktu widzenia m.in. reguł ekonomicznej analizy prawa. Instytucjonalizacja stosunków międzynarodowych i budowa wielopoziomowych systemów zarządzania wiodła do kosmopolityzacji prawa w ramach coraz bardziej popularnego multilateralizmu (Ikenberry, 2011, s. 56-68). Przeniesienie niektórych kompetencji państw narodowych na rzecz organizacji międzynarodowych miało stanowić gwarancję dla biznesu prowadzącego interesy na skalę globalną i tym samym chroniło kapitał, umożliwiając maksymalizację jego zysków i minimalizację strat. Instytucje międzynarodowe, takie jak Bank Światowy, Światowa Organizacja Handlu czy Międzynarodowy Fundusz Walutowy stały się zatem nośnikiem liberalizmu, promując deregulację, znoszenie ceł i ograniczeń administracyjnych oraz swobód przepływu czynników produkcji w drodze nowych porozumień handlowych. Ekonomizacja stosunków międzynarodowych w skali 
globalnej miała zapewniać pokój i dobrobyt wszystkim ich uczestnikom. W tak ukształtowanym otoczeniu niemal równorzędnymi graczami dla państw narodowych stawały się korporacje o zasięgu światowym, korzystające z synchronizacji globalnych procesów gospodarczych na uwolnionych rynkach, co zapewniało lepszą alokację czynników produkcji i wzrost bogactwa. Kierując się prymatem gospodarki nad polityką, to podmioty prywatne miały odgrywać dominującą rolę w strukturze współzależnych stosunków gospodarczych. Warto zauważyć, że powyższe stało się rudymentem polityki zagranicznej państw zachodnich, co dodatkowo osłaniała potęga militarna USA (Keohane, 2012, s. 125-138).

\section{Wpływ kryzysów międzynarodowych na pojmowanie paradygmatu neoliberalnego - konteksty nurtu L\&E}

Istotnym sprawdzianem dla każdego systemu pozostaje kryzys, który poprzez ogólne pogorszenie dobrostanu społecznego może podważać legitymizację określonego układu polityczno-gospodarczego. Obniżenie poziomu autoryzacji struktur władzy skutkuje z kolei trudnościami we wdrażaniu działań antykryzysowych, które mogą nieść ze sobą koszty, i z tego powodu są niepopularne wśród obywateli. Zachwianie całego systemu niewątpliwie wiedzie do pogłębienia istniejących problemów oraz utrudnia ich ostateczne przezwyciężenie. Kryzys unaocznia zatem kruchość legitymizacji politycznej danej struktury, ujawniając jej wewnętrzne napięcia oraz sprzeczności.

Doktryna neoliberalna została postawiona przed tak poważnym testem po wybuchu kryzysu gospodarczego 2008/2009 r., gdy ze względu na postulaty „Too Big To (Let) Fail" okazało się, że duże firmy (szczególnie instytucje finansowe) muszą korzystać z pomocy w postaci pieniędzy podatników i interwencji rządowej. Przyjęto jednak wówczas, iż załamanie gospodarcze nastąpiło poprzez naruszenie zasad neoliberalnych, toteż nie doszło do znacznej korekty w zakresie polityki gospodarczej, a wręcz zaczęto lansować hasło „więcej tego samego” (Farnsworth i Irving, 2018, s. 461-481). System okazał się zatem odporny na krytykę i propozycję modyfikacji obranych wcześniej kierunków działania. W spojrzeniu na ten kryzys (i podobnie na późniejsze perturbacje strefy euro) dominowała bowiem percepcja wolnorynkowych ekspertów, którzy sugerowali, że załamanie gospodarcze jest efektem braku konsekwencji w przestrzeganiu istniejących zasad oraz ignorowaniu wniosków płynących m.in. z prac szkoły prawa i ekonomii (López-Castellano i García-Quero, 2019, s. 167-193). Toteż naturalną odpowiedzią w takiej sytuacji stał się powrót do neoliberalnej ortodoksji. Kryzys nie dopro- 
wadził do kompromitacji tej idei, choć - wedle niektórych badaczy - system wolnorynkowy nie ułatwiał wyjścia z zapaści, przedłużając jej trwanie z uwagi na brak odpowiednich narzędzi do skutecznej reakcji. Wartości liberalne zaczęto zatem postrzegać jako zagrożenie, gdyż w dobie perturbacji gospodarczych najistotniejsza staje się potrzeba zapewnienia stabilności, której mechanizmy rynkowe raczej nie gwarantowały. Stąd pojawił się pogląd, iż zagrożeniem dla demokracji liberalnej nie jest radykalizm, a wyjęty spod jakiejkolwiek kontroli rynek i mechanizmy kapitalistyczne, które osłabiają fundamenty Zachodu poprzez tworzenie gruntu pod konflikty społeczne.

Jednym z powodów tych sporów mogły być ujawniające się wówczas nierówności społeczne, które zainicjowały dojmujące animozje między bogatymi a biednymi. Dostępne badania wskazują, iż od lat 80 . XX w. stopniowo postępował proces pauperyzacji klasy średniej oraz prekaryzacji ludzi pracy (Brainard, 2019). Zamiast wolnorynkowej konwergencji i „skapywania” bogactwa, uwidoczniła się polaryzacja oraz erozja sfery socjalnej na Zachodzie (OECD, 2008), co znalazło potwierdzenie m.in. $\mathrm{w}$ analizach prowadzonych $\mathrm{w}$ oparciu o wskaźniki nierówności społecznych (tzw. współczynnik Giniego). Okazało się, że system kapitalistyczny może osłabiać podstawy demokracji ze względu na koncentrację kapitału wywierającego asymetryczny wpływ na sferę prawa i polityki. Ze swoimi cyklami koniunkturalnymi oraz wzrostem zadłużenia gospodarstw domowych omawiany paradygmat mógł wręcz prowadzić do rodzaju „deficytu demokracji”, stawiając pod znakiem zapytania jakość ochrony praw obywatelskich w tym systemie. Jednostki były bowiem zaledwie konsumentami, których pozycja rynkowa względem dużego biznesu doznawała osłabienia ze względu na niedostatek informacji oraz gorszą sytuację finansową. Ich status stawał się coraz bardziej niepewny z uwagi na elastyczne formy zatrudnienia oraz występujące okresowo skoki bezrobocia. Niebagatelnego znaczenia nabierała odpowiedź na pytanie, czy w cieszącym się przymiotem legalizmu i praworządności systemie, który zakładał deregulację i prywatyzację życia gospodarczego, wszyscy obywatele mają rzeczywiście równe szanse.

Po nadejściu kryzysu ekonomicznego okazało się, że podział na zwycięzców i przegranych w epoce globalizacji to nie tylko efekt swobodnej gry sił rynkowych, lecz także nierzadko rezultat konkretnych decyzji politycznych, podejmowanych przez najsilniejsze gospodarczo podmioty. Zapaść ta unaoczniła, że tzw. niewidzialną rękę rynku często zastępuje dominacja zglobalizowanego kapitału, który powoduje, iż nie zawsze zyskują najbardziej przedsiębiorcze, pracowite i innowacyjne jednostki. To po stronie elit finansowych leżała do tej pory decyzja o rozkładzie władzy społecznej, co doprowadziło do głębokich rozwarstwień na 
tle socjalnym (MacLeavy, 2019, s. 627-640). Poprzez prywatyzację w imię wzrostu efektywności doszło w istocie do jeszcze większej koncentracji bogactwa, które zaczęło stopniowo ingerować w procesy demokratyczne z uwagi na asymetryczny wpływ zderegulowanego sektora finansowego na system społeczno-ekonomiczny. Decyzje w gospodarce wolnorynkowej miały być pierwotnie podejmowane na bazie racjonalnych analiz przez technokratów dbających o dobro ogółu, ale okazało się, że często uwarunkowane są one interesami najbardziej wpływowych grup społecznych. Mimo niewątpliwej poprawy efektywności w gospodarce, zauważalne stawały się nierówności, ekskluzja społeczna, a nawet eksploatacja niektórych podmiotów postrzeganych jako niezdolne do sprostania kapitalistycznej konkurencji. System jawił się jako chciwy, bezwzględny i kwestionujący znaczenie takich wartości, jak empatia i solidaryzm społeczny (Whitham, 2018, s. 252-264).

Naczelnym problemem analizowanego schematu, szczególnie w dobie kryzysów ekonomicznych, które przecież miały odejść w zapomnienie wraz z implementacją prawideł prezentowanej doktryny, stało się zapewnienie legitymizacji owego neoliberalnego porządku światowego (Cleen i Glynos, Mondon, 2018, s. 649-661). W tym miejscu warto wskazać, że jego prawomocność miały wspierać instytucje ponadnarodowe, zapewniające prawa jednostek i mniejszości na poziomie wspólnotowym. Okazało się jednak, że projekty ponadnarodowe podkopały klasyczną demokrację narodową, prowadząc do rodzaju „deficytu demokratycznego" na forum organizacji integracyjnych (Grosse, 2019, s. 62-103). W odpowiedzi na powyższe doszło do aktywacji narodowego populizmu, negującego tolerancję i pluralizm na rzecz powrotu do tożsamości oraz korzeni danej społeczności. Skutkowało to często odrzuceniem tego, co obce i pochodzące z zagranicy, jako podważającego tradycyjną suwerenność. Wcześniej kapitał wydawał się być nastawiony na bezideowe poszukiwanie efektywności, jednak w dobie kryzysu wyszło na jaw, że kieruje się on przesłankami o podłożu partykularnym. Co więcej, nie był on pragmatyczny i racjonalny, a często doktrynerski i stricte polityczny.

Jedną z paradoksalnych konsekwencji neoliberalnej globalizacji stało się ograniczenie roli obywateli, którzy stopniowo przestawali być potrzebni ze względu na konieczność podejmowania skomplikowanych decyzji, wymagających wiedzy eksperckiej. Złożoność świata społeczno-gospodarczego nie sprzyjała merytorycznemu zaangażowaniu zwykłych jednostek, które musiały ustąpić miejsca technokratom. Władza społeczna zaczęła przesuwać się w kierunku elit zainteresowanych maksymalizacją zysku i koncentracją kapitału. Prowadziło to do wykluczenia gorzej uposażonych oraz wyparcia małych przedsiębiorstw 
przez korporacje, których misją nie była solidarność i odpowiedzialność społeczna. W tym sensie środki produkcji zostały przejęte przez największych, więc pozostałe podmioty miały utrudnione funkcjonowanie mimo kultu indywidualizmu i przedsiębiorczości. Dodatkowo sfera publiczna również została zagospodarowana przez podmioty prywatne (np. media społecznościowe), reprodukujące narracje wspierające dominację doktryny neoliberalnej. Zauważalny stał się przykładowo rodzaj sojuszu sił wolnorynkowych i postępowych z przedsiębiorstwami z obszaru Big Tech (GAFA, tj. Google, Apple, Facebook, Amazon), który obrał sobie za cel obronę wartości liberalnych nawet za cenę ich czasowego zawieszenia ${ }^{4}$. Popularne było przeświadczenie, że tylko biznes i korporacje będą w stanie wyprowadzić globalną gospodarkę z zapaści. Jednak władza ekonomiczna wydawała się być wyjęta spod państwowej kontroli (deregulacja) i skupiona w wąskim kręgu elit (prywatyzacja), a zatem nie poczuwała się ona do odpowiedzialności za sferę publiczną, pogłębiając poczucie „deficytu demokracji". Pomimo cykli wyborczych, prowadzących do alternacji rządów, władza społeczna i ekonomiczna zapewniała status quo oraz stałą reprodukcję polityki liberalnej (Pabst, 2016, s. 91). Zamiast spodziewanej konwergencji rozwój poszczególnych obszarów stawał się coraz bardziej nierównomierny, ponieważ triumfował $w$ istocie tzw. model polaryzacyjno-dyfuzyjny, wzmacniający centra kosztem zapóźnionych peryferii ${ }^{5}$.

$\mathrm{Z}$ tego punktu widzenia doktryna neoliberalna nie prezentowała się jako wcielenie „logiki historii”, ale raczej jako arcypolityczny program, mający swoich beneficjentów oraz przegranych. Neoliberalizm jawił się w istocie jako formuła rządów tworzonych przez silne jednostki, do których inni muszą się dostosować, podczas gdy sami ich twórcy robią to, gdy jest to dla nich korzystne (Giroux, 2017, s. 13-20). Niektórzy badacze nawet utożsamiali ten fenomen z władzą ponadnarodowych korporacji oraz elit finansowych, pochodzących głównie ze świata zachodniego, nad państwami peryferyjnymi (Zarycki, 2007, s. 5). Ze względu na obniżenie standardów życia oraz nierówności społeczne ten liberalny kontrakt między elitami a ludem zachwiał się, a gdzieniegdzie został nawet wypowiedziany (przykładowo tzw. brexit). Obecnie bunt klasy średniej

\footnotetext{
4 Na osobne opracowanie zasługuje przykładowo sprawa zawieszenia należących do byłego Prezydenta USA Donalda Trumpa kont w mediach społecznościowych.

5 Model polaryzacyjno-dyfuzyjny - koncepcja rozwoju społeczno-gospodarczego obszarów odznaczających się znaczącym poziomem zróżnicowania wewnętrznego, zakładająca podejmowanie działań mających na celu wzmocnienie centrów (polaryzacja), które w konsekwencji staną się kołem zamachowym dla rozwoju i konwergencji peryferiów (dyfuzja). Na gruncie polskim model ten został szerzej omówiony w Raporcie „Polska 2030. Wyzwania rozwojowe”, przygotowanym pod redakcją Michała Boniego (Boni, 2009).
} 
i pracującej może oznaczać powrót do nacjonalizmów, ksenofobii, kontestowania obcych oraz oporu wobec międzynarodowych korporacji (Virdee i McGeever, 2018, s. 1802-1819).

Po doświadczeniu załamania gospodarczego pojawiło się przekonanie, że nierówności są immanentną cechą kapitalizmu, a nie jego anomalią. Wymagają one zatem interwencji ze strony państwa, inaczej dochodzi do podkopania fundamentów demokracji z uwagi na dominację bogatych oraz stopniową prekaryzację klasy średniej. Niedostatek nadzoru nad rynkami finansowymi i kapitałem spekulacyjnym może bowiem sprzyjać powstaniu rodzaju oligarchistycznego kapitalizmu. Państwo traci suwerenność w tych sferach, w których dochodzi do konfliktu z kapitałem, a globalizacja i związane z nią uwolnienie rynków finansowych mogą powodować niestabilność gospodarczą. Jej rezultatem wydaje się być ograniczenie władzy ekonomicznej państw, osłabienie demokracji, a także kontroli społecznej nad procesami gospodarczymi oraz zmajoryzowanie rynków przez interesy partykularne, które osłabiają solidarność społeczną na rzecz egoizmu. Zdaniem badaczy takie rozumienie liberalizmu prowadzi do bagatelizowania roli ładu gospodarczego, w ramach którego wolność jednostki służyłaby nie tylko interesom elit, lecz także zaspokajałaby potrzeby większości społeczeństwa. Owa „wolność bez ładu” może bowiem doprowadzić do chaosu i generowania kolejnych kryzysów gospodarki światowej, toteż koniecznością staje się m.in. refleksja na temat myśli ordoliberalnej, promującej ideę „wolności w ramach ładu" (Mączyńska i Pysz, 2014, s. 65-90).

Światowa pandemia COVID-19 niestety tylko pogłębiła problemy (Saad-Filho, 2020, s. 477-485), które ujawniły się wcześniej w trakcie zapaści ekonomicznej 2008/2009 r., a także były widoczne na tle późniejszych wyzwań migracyjnych Europy oraz turbulencji w państwach strefy euro. W tym sensie kolejne kryzysy nadwątliły fundamenty neoliberalizmu, a epidemia zadała potężny cios tej doktrynie, skutkując koniecznością ograniczenia praw obywatelskich oraz swobód rynkowych. Zakwestionowano wówczas zasadę wolnego przepływu kapitału, wstrzymano dostawy produktów, a także ograniczono transport międzynarodowy. Okazało się, że Zachód nie jest w stanie sam wyprodukować potrzebne dobra i towary bez udziału Chin (Stahl, 2020). Rozregulowany rynek pracy doprowadził do tego, że miliony osób zatrudnionych na zasadzie elastycznych form prawnych z dnia na dzień straciły źródło utrzymania. Państwa musiały podjąć zakrojoną na szeroką skalę interwencję w gospodarce, by ratować wiele firm od bankructwa, ponieważ wolny rynek okazał się bezradny w konfrontacji z pandemią koronawirusa. Znaczące koszty tego kryzysu zostały jednak ulokowane w warstwach społecznych, które do tej pory najmniej skorzystały z dobrodziejstw gospodarki 
wolnorynkowej. Uwidoczniła się problematyczność hipotezy, iż neoliberalna globalizacja „podnosi wszystkie łodzie” w zakresie bogacenia się społeczeństw i państw, podkopując równocześnie zasadność kierowania się m.in. metodami nurtu $L \& E$ w polityce i gospodarce.

Omawiany paradygmat często prezentowano jako spontaniczny, samorzutny ład rynkowy, wolny od wpływu ideologii, którego krytyka jawiła się jako nierozsądna. Jednak wydaje się, że neoliberalna globalizacja przyczyniła się do pozbawienia szerokich segmentów społeczeństw panowania nad własnym losem, gdyż odmówiono tym grupom - w imię wyższej racjonalności - możliwości prowadzenia polityki według innych niż wolnorynkowe preferencji. W trakcie kryzysów obecna była intelektualna ortodoksja, której strażnicy nie tolerowali znaczących odstępstw. Tymczasem wiarygodność neoliberalnego dogmatu w zakresie przekonania, że droga do powszechnego dobrobytu wiedzie przez nieskrępowany wolny rynek, utraciła na znaczeniu (Peck i Theodore, 2019, s. 245-265). Konsekwencją jest wyraźna polaryzacja społeczna, prowadząca do utraty zaufania tak do elit, jak i do teorii, na których opierał się neoliberalny model gospodarki, oraz do systemu politycznego, stanowiącego jego ramy instytucjonalne. W praktyce występują całe obszary społeczeństw zachodnich niemające politycznej reprezentacji. Transmisja ich preferencji na poziom krajowy czy zagraniczny pozostaje wątpliwa i w efekcie faktem staje się wykluczeniem, które w sytuacji kryzysu czyni system niestabilnym.

Rodzaj depolityzacji władzy na rzecz jej ekonomizacji poprzez wzmocnienie roli prywatnego kapitału został negatywnie oceniony przez lud, gdyż poderwał on ochronę praw jednostek doświadczających społecznej marginalizacji (Öniş, 2017, s. 21). W krajach pogrążonych w kryzysie wyborcy sprzeciwili się kolejnym oszczędnościom narzucanym przez instytucje międzynarodowe i przedstawicieli krajów będących największymi wierzycielami. Domagali się oni bowiem bardziej sprawiedliwej dystrybucji kosztów kryzysu. Natomiast w bogatszych państwach obywatele zbuntowali się przeciw nadmiernej dystrybucji funduszy z ich podatków na rzecz ratowania gospodarek innych krajów, negując tym samym zasadę solidarności obowiązującą przykładowo w strukturach integracyjnych, takich jak Unia Europejska. Kryzys powinien był mobilizować do poszukiwania rozwiązań demokratycznych, aby skutecznie rozwiązać zaistniałe problemy (Wood i Flinders, 2014, s. 151-170). W wyniku turbulencji uruchomiona została demokracja na poziomie narodowym, co skutkowało - przynajmniej w niektórych państwach - intensywną presją na odzyskanie kontroli przez krajowe instytucje wyborcze nad lokalną polityką oraz zwiększeniem nadzoru nad procesami globalizacyjnymi (Krastev, 2016, s. 88). Wzmocniło to wspólnoty 
narodowe występujące w roli strażników legitymizacji demokratycznej kosztem fenomenu ponadnarodowej instytucjonalizacji. Społeczeństwa demokratyczne, oczekując trwałego wzrostu oraz bezpieczeństwa, zareagowały na sytuację zagrożenia żądaniem kompleksowej i skutecznej odpowiedzi ze strony politycznych decydentów i doznały rozczarowań, czego rezultatem były późniejsze demokratyczne wybory. Konsekwencją powyższego trendu była m.in. decyzja Prezydenta USA D. Trumpa o wystąpieniu Stanów Zjednoczonych z paryskiego porozumienia klimatycznego ${ }^{6}$, którego implementacja - zdaniem niektórych badaczy - mogła wiązać się z przerzucaniem kosztów nowej polityki ochrony środowiska naturalnego na mniej zasobne segmenty amerykańskiego społeczeństwa. Co więcej, D. Trump podjął decyzję o wystąpieniu USA ze Światowej Organizacji Zdrowia (WHO) z uwagi na spóźnioną - w jego ocenie - reakcję tej organizacji na pandemię koronawirusa.

Zachód staje się aktualnie obszarem wielu problemów, do których można zaliczyć chociażby kryzys migracyjny, finansowy oraz geopolityczny, a także ten związany z pandemią COVID-19. Dostrzegalna jest nieumiejętność strategicznej odpowiedzi na te wyzwania, co ustępuje raczej doraźnym działaniom, zmierzającym do zachowania zrębów istniejącego systemu. Panuje przekonanie, że ostatnie zjawiska są objawem problemów neoliberalnej formuły kapitalizmu, którą cechują rosnące nierówności społeczne, nadmierna deregulacja rynków oraz spekulacja ze strony instytucji finansowych. Taki model rozwoju, który oparto o doktrynę neoliberalną, był początkowo funkcjonalny, ale z biegiem czasu okazał się on pułapką przynoszącą zadłużenie, wzrost inflacji oraz malejącą konkurencyjność.

Z uwagi na powyższe trudności w sferze gospodarczej w polityce międzynarodowej daje się aktualnie zaobserwować stopniowe zastępowanie multilateralizmu poprzez konfrontację geopolityczną największych mocarstw odznaczających się odmiennymi systemami społeczno-gospodarczymi i politycznymi. Zjawisko to jest konsekwencją osłabienia struktur Zachodu, a zarazem równoczesnego, relatywnego wzrostu znaczenia podmiotów z innych części globu, zachęconych do kontestowania dotychczasowego porządku światowego (np. Chiny). W tym kontekście aktualnie obserwowany rozwój badań nad paradygmatem geopolitycznym jawi się jako jeden z syndromów dekoniunktury liberalnej teorii stosunków międzynarodowych. Zdaniem niektórych badaczy wielostronne

6 W dniu 12 grudnia 2015 r. państwa uczestniczące w Konferencji Narodów Zjednoczonych w sprawie zmian klimatu, Paryż 2015 (COP21), zgodziły się na przyjęcie porozumienia globalnego - paryskiego porozumienia, według którego ma nastąpić redukcja emisji jako część sposobu na zmniejszenie emisji gazów cieplarnianych. 
organizacje o liberalnej proweniencji ułatwiły rozlewanie się kryzysów, nie zawsze stanowiąc efektywne narzędzie zapobiegania lub przezwyciężania tych wyzwań. Panowało przeświadczenie, że stosunki międzynarodowe są pokojowe w gronie demokracji liberalnych, jednak w istocie kapitalistyczna gospodarka okazała się rodzajem nowej wojny, w której udział bierze biznes międzynarodowy nastawiony na realizację partykularnego interesu. Pojawiły się ponadto problemy legitymizacyjne, gdyż formy organizacji politycznej wykraczające poza państwo narodowe wykazały się sporym „deficytem demokracji”. Międzynarodowy porządek liberalny doprowadził do polaryzacji wśród państw zachodnich, z których te peryferyjne doświadczyły rodzaju drenażu, a zarazem braku solidarności (Ingraham, 2017, s. 27). Okazało się, że nie każdy problem może być rozwiązany przez rynek i międzynarodową supranacjonalizację oraz nie każda umowa handlowa jest korzystna dla wszystkich jej uczestników. Zaobserwować można było presję na państwach-dłużnikach, od których żądano spełnienia dodatkowych wymogów w zamian za potrzebne finansowanie, demaskując rodzaj fasadowości ich demokracji. Przykładowo Europa Środkowo-Wschodnia przyjęła neoliberalizm w ramach transformacji ustrojowej i gospodarczej ze względu na nacisk geopolityczny Zachodu, którego wytyczne odczytywano jako spełnienie nowoczesnych standardów. Obecnie presja ta wydaje się słabnąć ze względu na wielowymiarowy kryzys państw zachodnich, co zwiastować może odejście od demokracji liberalnej na peryferiach wskazanego obszaru (Junes, 2016, s. 9). Wiodąca ideologia Zachodu, która jest z założenia uniwersalistyczna, powoli ustępuje miejsca bardziej zróżnicowanym strukturom kulturowym, społecznym i gospodarczym w skali regionalnej. Te różnice między wiodącą doktryną a lokalnymi uwarunkowaniami powodują rozdźwięk w sferze ekonomicznej i politycznej, coraz bardziej zauważalny na forum takich gremiów jak np. Unia Europejska.

\section{Zakończenie}

Sekwencja rozmaitych kryzysów dotykających neoliberalne struktury Zachodu skłania do przyjrzenia się problematyce dekompozycji tego systemu, której objawem jest m.in. znaczący wzrost nierówności społecznych. Z każdym kolejnym załamaniem obniżeniu ulega znaczenie omawianej strefy, czego wyrazem staje się m.in. relatywny wzrost pozycji systemowej mocarstw z innych części świata (np. Chiny). Biorąc pod uwagę powyższe, system zachodni można postrzegać coraz bardziej jako pole konfliktów społeczno-gospodarczych w Europie i Stanach 
Zjednoczonych, mogących zwiastować koniec neoliberalnej epoki w polityce międzynarodowej, a zarazem dekompozycję multilateralnych instytucji, które do tej pory pełniły rolę pasa transmisyjnego doktryny neoliberalnej na świecie.

Coraz bardziej ewidentne nierówności społeczne, upadek znaczenia klasy średniej oraz dominacja elit finansowych przywołują na myśl wizje urządzeń społecznych funkcjonujących do tej pory na marginaliach. Z tego punktu widzenia kryzysy jawią się jako katalizator konfliktów, które powodują zwrócenie się Zachodu przeciwko sobie. Przykładowo peryferia systemu zachodniego nie wykazują już dawnej gorliwości do imitowania struktur integracyjnych, co znajduje odzwierciedlenie w aktualnych procesach społeczno-politycznych Europy Środkowo-Wschodniej. Wstrząsy te uaktywniły demokrację na poziomie narodowym, co uruchomiło tendencje do renacjonalizacji, które są wymierzone m.in. w instytucje ponadnarodowe, postrzegane coraz częściej, wbrew m.in. paradygmatowi szkoły prawa i ekonomii, jako źródło egzystencjalnych zagrożeń. Doszło do zachwiania roli międzynarodowych gremiów, które funkcjonowały do tej pory jako ekspozytura idei wolnorynkowych.

Wielość kryzysów skłania do stawiania pytań o zupełnie nowy system mogący w przyszłości zastąpić nadwątlone, neoliberalne struktury Zachodu. W tym miejscu warto wskazać, iż przekonującej odpowiedzi na te dylematy raczej nie należy spodziewać się ze strony tzw. narodowych populistów, którzy kontestują zastane paradygmaty, niekoniecznie mając receptę na budowę nowego ładu. Ich jedynym postulatem jest walka $z$ dotychczasowym establishmentem, który wydaje się z kolei proponować kontynuację dawnych schematów postępowania w myśl hasła „więcej tego samego", pomimo symptomów erozji omawianej doktryny.

Biorąc pod uwagę powyższe, ekonomiczna analiza prawa może być postrzegana jako przydatne narzędzie badawcze do prowadzenia analiz w zakresie efektywności doktryny neoliberalnej w przestrzeni międzynarodowej. Paradygmat szkoły prawa i ekonomii jest i będzie wykorzystywany do objaśniania fenomenu powstawania, a także działania instytucji wolnorynkowych w aspekcie regionalnym i/lub globalnym. Zakwestionowaniu ulega jednak użyteczność tego modelu w zakresie refleksji dotyczącej m.in. wpływu zjawisk kryzysowych na funkcjonowanie neoliberalizmu. Istota tej metody opiera się bowiem na przeświadczeniu, iż efektywność ekonomiczna stanowi kluczową wartość, którą kierują się aktorzy polityki i gospodarki. Można zatem zasadnie powątpiewać, czy szkoła ta jest w stanie dostrzec szerokie spektrum czynników, które mogą mieć wpływ na zjawisko kryzysu neoliberalizmu. Chociaż paradygmat ten wciąż charakteryzuje się istotnym poziomem przydatności w rozważaniach dotyczących procesów liberalizacyjnych w różnych regionach globu, to wartość poznawcza ekono- 
micznej analizy prawa ujawnia szereg ograniczeń w odniesieniu do eksplanacji przyczyn, przebiegu oraz skutków aktualnych turbulencji międzynarodowych.

\section{Bibliografia}

Bairoch, P. i Kozul-Wright, R. (1998). Globalization Myths. Some Historical Reflections on Integration, Industrialization and Growth in the World Economy. W: P. Bairoch, R. Kozul-Wright (red.), Transnational Corporations and the Global Economy (s. 37-68). London: Palgrave Macmillan.

Boni, M. (2009). Polska 2030. Wyzwania rozwojowe. Warszawa: Kancelaria Prezesa Rady Ministrów.

Brainard, L. (2019). Is the Middle Class within Reach for Middle-Income Families?, wystąpienie na konferencji pt. „Renewing the Promise of the Middle Class” Federal Reserve System Community Development Research Conference. Washington D.C. Pobrano z https://www.federalreserve.gov/newsevents/ speech/brainard20190510a.htm (25.05.2021).

Cooter, R. i Ulen, T. (2011). Ekonomiczna analiza prawa (red. nauk. tłum. J. Bełdowski, K. Metelska-Szaniawska; tłum. J. Bełdowski i in.). Warszawa: Wydawnictwo C.H. Beck.

Dawson, J. i Hanley, S. (2016). The Fading Mirage of the "Liberal Consensus". Journal of Democracy, 27(1), 20-34.

De Cleen, B., Glynos, J. i Mondon, A. (2018). Critical research on populism. Nine rules of engagement. Organization, 25(5), 649-661.

Diamond, L. (1999). Developing Democracy. Toward Consolidation. Baltimore: Johns Hopkins University. Press..

Duménil, G. i Lévy, D. (2011). The Crisis of Neoliberalism. Cambridge: Harvard University Press.

Dunne, T. (2008). Liberalism. W: A. Baylis, S. Smith, P. Owens (red.), The Globalization of World Politics (s. 110-121). New York: Oxford University Press.

Farnsworth, K. i Irving, Z. (2018). Austerity. Neoliberal dreams come true? Critical Social Policy, 38(3), 461-481.

Giroux, H. (2017). Authoritarianism, class warfare, and the advance of neoliberal austerity policies. Knowledge Cultures, 5(1), 13-20.

Glyn, A. (1998). Internal and external constraints on egalitarian policies. W: D. Baker, G. Epstein, R. Pollin (red.), Globalization and Progressive Economic Policy (s. 391-409). Cambridge: Cambridge University Press.

Grosse, T.G. (2019). Kryzys Zachodu w świetle koncepcji Arnolda Toynbeego. W: M.A. Cichocki (red.), Wspótczesne państwa a kryzys liberalnego Zachodu (s. 62-103). Warszawa: Centrum Europejskie Natolin. 
Ikenberry, G.J. (2011). The future of the liberal world order: internationalism after America. Foreign Affairs, 90(3), 56-68.

Ingraham, L. (2017). Billionaire at the Barricades. The Populist Revolution from Reagan to Trump. New York: All Points Books.

Junes, T. (2016). Illiberalism and authoritarianism can be successfully challenged in Poland, OpenDemocracy. Free Thinking for the World.

Keohane, R. (2012). Twenty years of institutional Liberalism. International Relations, 26(2), 125-138.

Kotz, D.M. (2001). The State, Globalization, and Phases of Capitalist Development. W: R. Albritton, M. Itoh, R. Westra, A. Zuege (red.), Phases of Capitalist Development. Booms, Crises and Globalizations (s. 93-109). Hampshire-New York: Palgrave Press.

Krastev, I. (2016). The Unraveling of the Post-1989 Order. Journal of Democracy, 27(4), 88-98.

López-Castellano, F. i García-Quero, F. (2019). The Euro System as a Laboratory for Neoliberalism. The Case of Spain. The American Journal of Economics and Sociology, 78(1), 167-193.

MacLeavy, J. (2019). Neoliberalism and the new political crisis in the West. Ephemera. Theory \& Politics in Organization, 19(3), 627-640.

Mączyńska, E. i Pysz, P. (2014). Liberalizm, neoliberalizm i ordoliberalizm. W: E. Mączyńska (red.), Ekonomia dla przyszłości. Fundamentalne problemy teorii ekonomii i praktyki gospodarczej. IX Kongres Ekonomistów Polskich (s. 65-90). Warszawa: Polskie Towarzystwo Ekonomiczne.

OECD. (2008). Growing Unequal?: Income Distribution and Poverty in OECD Countries. Pobrano z https://read.oecd-ilibrary.org/social-issues-migration-health/ growing-unequal_9789264044197-en\#page2 (25.05.2021).

Öniş, Z. (2017). The Age of Anxiety: The Crisis of Liberal Democracy in a Post-Hegemonic Global Order. The International Spectator, 52(3), 18-35.

Pabst, A. (2016). Is Liberal Democracy Sliding into "Democratic Despotism". Political Quarterly, 87(1), 91-95.

Peck, J. i Theodore, N. (2019). Still neoliberalism? South Atlantic Quarterly, 118(2), 245-265.

Saad-Filho, A. (2020). From COVID-19 to the End of Neoliberalism. Critical Sociology, 46(4-5), 477-485.

Stahl, G. (2020). The reconstruction of the European economy after the Corona pandemic. The Progressive Post. Pobrano z https://progressivepost.eu/ spotlights/the-reconstruction-of-the-europeans-economy-after-the-corona-pandemic (25.05.2021). 
Virdee, S. i McGeever, B. (2018). Racism, crisis, Brexit. Ethnic and Racial Studies, 41(10), 1802-1819.

Wallerstein, I. (1974). The Modern World System. Capitalist Agriculture and the Origins of the European World Economy in the Sixteenth Century. New York: Academic Press.

Whitham, B. (2018). Post-crash neoliberalism in theory and practice. Political Studies Review, 16(4), 252-264.

Wood, M. i Flinders, M. (2014). Rethinking depoliticization. Beyond the governmental. Policy \& Politics, 42(2), 151-170.

Zarycki, T. (2007). Interdyscyplinarny model stosunków centro-peryferyjnych. Propozycje teoretyczne. Studia Regionalne i Lokalne, 1(27), 5-26.

\section{Streszczenie}

W artykule skoncentrowano się na analizie funkcjonowania idei neoliberalnych w kontekście rozmaitych kryzysów dotykających aktualnie Zachód. Jego hipotezą jest stwierdzenie, że neoliberalizm - będąc doktryną tam uformowaną - przyczynia się do stopniowej transformacji struktur świata zachodniego, których znaczenie polityczno-gospodarcze w wyniku zachodzących zmian - sukcesywnie się obniża. Ze względu na rosnące nierówności społeczne architektura społeczno-gospodarcza Zachodu upodabnia się coraz bardziej do gremiów, które do tej pory występowały na obszarach peryferyjnych. Dostrzeganą tam reakcją na powyższy fenomen jest m.in. wzrost znaczenia radykalizmów, które kontestują zastane paradygmaty w dziedzinie polityki i ekonomii. Mimo licznych kryzysów dotykających zachodnie struktury władzy i gospodarki nadal zauważyć można tam dominację analizowanej ideologii. Coraz częściej do głosu dochodzi jednak przekonanie o końcu neoliberalnej ery w stosunkach międzynarodowych, prowadzącym potencjalnie do dekompozycji multilateralnych instytucji polityki światowej, które dotychczas stanowiły pas transmisyjny m.in. dla idei neoliberalnych.

SŁoWA KLUCzowE: neoliberalizm, kryzysy, reżimy międzynarodowe.

\section{Summary}

The article focuses on the analysis of the functioning of neo-liberal ideas in the context of various crises currently affecting the West. Its hypothesis is the statement that neoliberalism - a doctrine formed there - contributes to a gradual transformation of the structures of the Western world, the political and economic significance of which - as a result of the changes taking place - is gradually decreasing. Due to increasing social inequalities, the political and socio-economic architecture of the West is becoming more and more similar to the ones that have so far existed in the peripheral areas. The perceived reaction to the above phenomenon is, among others, increasing importance of the radical movements that challenge the existing paradigms in the field of politics and economics. Despite numerous crises affecting Western structures of power and economy, the dominance of the analysed ideology is still noticeable there. However, 
a conviction that the neo-liberal era in international relations is about to end is emerging. It is potentially leading to the decomposition of multilateral institutions of world politics, which so far has been a transmission belt for neo-liberal ideas.

KeYwords: neoliberalism, crises, international regimes.

\section{Nota o autorze}

Artur Niedźwiecki - dr, Uniwersytet Łódzki; główne obszary działalności naukowej: prawo gospodarcze, integracja międzynarodowa; e-mail: a.niedzwiecki@yahoo.pl; ORCID: 0000-0002-2683-5319. 
